\title{
Team Assignment Method in Improving Nurse Performance in Hospital
}

\author{
Lin Herlina ${ }^{1}$, Tri Kurniati² and Abdul Aziz Alimul Hidayat ${ }^{3}$ \\ ${ }^{1,2}$ Department of Nursing, University of Muhammadiyah Jakarta, Indonesia \\ Jl. Cempaka Putih Tengah I/1, Kota Jakarta Pusat, DKI Jakarta, 10510 \\ ${ }^{3}$ Departement of Nursing, University of Muhammadiyah Surabaya, Indonesia \\ Jl. Raya Sutorejo No. 59, Mulyorejo, Kota Surabaya, 60113 \\ *Corresponding author: linherlinasubandi@yahoo.com
}

\begin{abstract}
Background: Nurse Performance is part of a component that contributes to improving hospital service quality. Problems in hospitals are still many hospitals that have problems of nurse performance, especially in RS Cirebon Indonesia. One solution is the application of team assignment methods in nursing care. Objective: The purpose of this paper is to analyze the influence of team assignment method in improving nurse's performance in hospital through cross sectional research design. Method: This was a quantitative research. Sample size was 267 taken by purposive sampling. Data was analyzed with chi-square. Result: there is overall influence of team assignment on nursing performance $p=0.000$, while elements in team assignment also have influence, among others; planning $p=0.001$, organizing $p=0.067$, briefing $p=0.000$, and supervision $p=0.000$. Conclusions: The performance of hospital nurses can be improved through the application of team assignment methods in nursing care.
\end{abstract}

Keywords: Team Assignment Method, Nurse Performance, Planning, Organizing, Direction and Supervision

\section{INTRODUCTION}

The contribution of the nurses can determine the quality of service in the hospital, so the hospital should strive to improve the quality of nursing service (Hamid, 2012). According to Aiken (2010) explains that the implementation of professional nursing services can be done by the method of assignment. The assignment method consists of five functional methods, team method, primary method, case method and primary-level nursing method. The method of assignment developed in Indonesia is the team method. Team method is the method most applied by nurses in providing nursing. Team methods employ teams of different members, in providing nursing care to a group of patients. Team methods can provide a higher sense of nurse responsibility resulting in improved patient performance and satisfaction (Nursalam, 2014).

The success of the team method is determined by the team leader's ability to assign assignments to team members and direct his team's work. The nurse who plays the role of the team leader is responsible for knowing the conditions and needs of all the patients in his team and planning the patient's care. The team leader's job includes: reviewing team members, providing care directives for patients, conducting health education, coordinating patient activities (Tappen et al, 2010). In addition, the role of the head of space is also very important in the implementation of team method that is as a resource for the team leader (Sitorus and Panjaitan, 2011). The purpose of this study is to analyze the influence of the method of Assignment of Team against Performance Nurse Implementation at General Hospital Area Cirebon Year 2017. 


\section{METHOD}

This research is a quantitative research, Cross Sectional research descriptions. The population in this study was 811 nurses. Sampling method with Purposive Sampling technique by looking at sample criterion. The sample size is 267 respondents. How to collect data by interview, and observation. Data analysis was done using Chi-square. While multivariate analysis using multiple logistic regression.

\section{RESULT AND DISCUSSION}

Table shows the most characteristic of each characteristic that is at age characteristic of respondent from age 31 - 40 year with number of respondent as much $182(68,16 \%)$, female gender characteristic more dominant that is $196(73,41 \%)$ more compared to men, education characteristics at bachelor level and profession with the number of $151(56,55 \%)$ and for respondent characteristic at the most time of work that is 5-10 years experience $(44,19 \%)$ compared to other working period.

Table 1 Distribution of frequency of respondents based on the characteristics (age, sex, education and length of work) of respondents at RSUD Cirebon

\begin{tabular}{|c|c|c|c|}
\hline No & Variable & $\mathrm{f}$ & $\%$ \\
\hline \multirow[t]{4}{*}{1.} & Age: & & \\
\hline & Age 21 - 30 years & 65 & $24.34 \%$ \\
\hline & Age $31-40$ years & 182 & $68.16 \%$ \\
\hline & Age $>40$ years & 20 & $7.49 \%$ \\
\hline \multirow[t]{3}{*}{2.} & Gender & & \\
\hline & Male & 71 & $26.59 \%$ \\
\hline & Women & 196 & $73,41 \%$ \\
\hline \multirow[t]{4}{*}{3.} & Education & & \\
\hline & D3 Nursing & 103 & $38.58 \%$ \\
\hline & S1 Nursing and Profession 151 & $56.55 \%$ & \\
\hline & S2 Nursing $134.87 \%$ & & \\
\hline \multirow[t]{4}{*}{4.} & Long Working & & \\
\hline & $<5$ years & 104 & $38.95 \%$ \\
\hline & $5-10$ years & 118 & $44.19 \%$ \\
\hline & $>10$ years & 45 & $16.85 \%$ \\
\hline
\end{tabular}

In Table 2. shows the results of the analysis is known that the nurses at RSUD Cirebon on team assignment methods performed on each indicator that only on the directive function that has poor results on the performance of nurses implementing.

Discusses the implementation of team assignment methods that will lead to behavior and deliver performance in the form of performance. This is because whatever is felt and done that will be applied in the work environment will produce performance. Factors that affect the execution of team methods both internal and external that cause a person to choose the path and act that will produce performance in accordance with the results obtained which will be assessed whether the performance is good or not good. The performance is whether the positive later that is to produce a good performance or a negative performance that will result in poor performance (Suyatno, 2015). Ideally this behavior will be directed at achieving the objectives of the team assignment method in this case measured by the person's performance. Performance is the result achieved by a person according to the size applicable to the HR concerned in the implementation of the team assignment method based on several factors that can affect the achievement of a performance (Wibowo, 2013). 
Table 2 Effect of Team Assignment Method on Performance of Nurse Executor in RSUD Cirebon

\begin{tabular}{|c|c|c|c|c|c|c|}
\hline \multicolumn{7}{|c|}{ Performance of Nurse Executives } \\
\hline Variable & $\begin{array}{c}\text { Less } \\
\mathrm{N} \%\end{array}$ & $\begin{array}{r}\text { Good } \\
\mathrm{n} \%\end{array}$ & $\begin{array}{c}\text { Total } \\
\mathrm{n} \%\end{array}$ & $\begin{array}{c}\text { OR } \\
\text { Value }\end{array}$ & $\mathrm{P}$ & \\
\hline \multicolumn{7}{|c|}{ Team Assignment Method } \\
\hline Less Good & 57 & 45.2 & 69 & 54.8 & 126100 & \\
\hline Good & 62 & 44,079 & 56,0 & 141 & 1001.5 & 0.001 \\
\hline \multicolumn{7}{|l|}{ Organizing } \\
\hline Less Good & 48 & 44.9 & 59 & 55.1 & 107100 & \\
\hline Good & 75 & 46.9 & 85 & 53.1 & 1601005.21 & 0.067 \\
\hline \multicolumn{7}{|l|}{ Direction } \\
\hline Not Good & 88 & 55.8 & 67 & 42.2 & 155100 & \\
\hline Good & 62 & 55.4 & 50 & 44.6 & 1121001,215 & 0,000 \\
\hline \multicolumn{7}{|l|}{ Supervision } \\
\hline Less Good & 45 & 39.5 & 69 & 60.5 & 114100 & \\
\hline Good & 61 & 39.9 & 60.1 & 153100 & $2,210,000$ & \\
\hline
\end{tabular}

These factors make the individual in the implementation of team assignment methods are different from each other and will affect the individual in perceiving an object, stimulus, although the object is really the same. In the execution of team or group assignment methods can be much different even if the situation is the same. Differences can be traced to individual differences, differences in personality, differences in attitudes or differences in motivation. This will all affect the behavior of individuals or groups in the execution of team assignment methods and will be generated on the performance of the individual or group of people.

The behavior of a person on the basis is inseparable from the underlying motives. Behavior forms within itself in terms of team assignment methods. This can be viewed contextually, meaning situations where behavior in the team's assignment method arises, should receive attention. Situation is a contributing factor in the process of establishing one's behavior in applying the team's assignment method. If the method of assigning the team to the objects that are judged to be good then it will get the results of rising performance as well vice versa. Meanwhile, as a social being, a person wants a relationship and cooperation with other social beings, therefore he tries to adjust to the environment in which he works. Thus it can be concluded that the method of assigning a good team to the object that is judged will have a good performance impact as well, otherwise the implementation of poor team assignment method will result in poor performance.

This is in accordance with research conducted by Cindy et al (2017) said that the performance of most inpatient nurses has a good performance with the value $p=0.020<\alpha=$ 0.05 indicates there is a relationship between the implementation of team methods with the performance of nurses implementing. But of the many who have good performance, there is still a poor performance. Such conditions need to be traced factors - factors associated with the performance so that the expected assessment of the performance of nurses is a repair or improvement of work motivation of all nurses implementing. This is in accordance with the research conducted that the performance of nurse implementers here is how documenting nursing care done, the speed and responsiveness of the respondents how the nurse implementers create or maintain cooperation relationships with other health workers. 
Based on research conducted Kuswantoro (2012), about the effect of implementation of managerial function in the method of assigning the team to the performance in RSU dr. Saeful Anwar Malang obtained statistical test result can be explained that the managerial function has an effect on the performance of nurse implementer with $p$ value 0.000 . This is the same as that done by the researcher in this case the managerial function in which there is planning, organizing, directing and supervision is in the method of assigning a team that examines the managerial functions.

\section{CONCLUSION}

In improving the performance of nurses in the hospital one of the alternatives is to apply the team assignment method in nursing care, ranging from planning, organizing, directing and supervision. For that the hospital management can consider the approach of this method to be applied.

\section{ACKNOWLEDGEMENT}

Researchers would like to thank all those who have assisted the data collection process used in this study.

\section{REFERENCE}

Aiken (2010), Nurses Report on Hospital Care in Five Countries Health Affair.

Cindy, Linnie, Rivelino (2017), Relationship of Team Method Implementation With Performance of Nurse Executor in IRINA C RSUP Prof. Dr. R. D. Kandow Manado. $e$ - Journal kep (e - kp). Nursing Science Program, Sam Ratulangi University.

Hamid., Y., A (2012), Care of Quality Nursing at Hospital Hospital Data and Information Center (http: //www.pd pers.co.id).

Nursallam (2014), Nursing Management: Applications In Nursing Practice. Issue 4, Jakarta: Salemba Medika.

Kuswantoro, R (2012), The Effect of Implementation of Managerial Functions of Room Chief in Method of Team Assignment to Performance of Team Leader Dr. RSU. Saeful Anwar Malang. $e$ - journal management and leadership of faculty of medicine, University of Brawijaya.

Rahmat, Kurnia and Sedyowinarso (2012), The Nursing Care Documentation Relationship With The Performance of The Nurse Implementing. Thesis.

Sitorus., R. Panjaitan., R (2011), Nursing Management: Management Nursing In The Out Room. Jakarta : Sagung Seto.

Suyatno (2015), Know Your Leadership and Nursing Management at Yogyakarta Hospital : Partners.

Tappen., R., M., Weis, S.A and Whitenead, D.K (2010), Essential of Nursing Leadership and Management, Philadelphia : F.A.Davis Company 
Wibowo (2013), Work Management. Jakarta : Rajawali Pers 